\title{
TOPLUMSAL BELLEK VE SİNEMA: POPÜLER SİNEMA ÖRNEĞİ OLARAK FETİH 1453
}

\author{
Nermin Orta*
}

\section{ÖZET}

Toplumsal bellek, toplumun geçmişe ait olaylarla tanışık olması, kimi zaman geri gidebilmesi demek, şeklinde tanımlanabilmektedir. Toplumsal bellek, yalnızca geçmişe ait verilerin bulunduğu ve gerektiğinde dönüp bakılan bir depo değ il, başl başına bir mücadele alanı ve politik bir süreç olarak görülmektedir. Bu anlamda, tarihin, ulusal kimliğin inşasında önemli bir çerçeve oluşturduğu söylenebilir. Buradan bakıldığında toplumsal belleğin yönlendirilebilir, yeniden inşa halindeki bir olgu olduğu görülmektedir.

Belleğin yeniden kurgulanmasında sanat, kitle iletişim araçları, sivil toplum ve özellikle anlatı oluşturma ve bağlam kurma konusunda sinema önemli rol oynamaktadır. Temsiller aracılığı ile gerçek dünyanın yeniden üretimini yapan sinemanın, bu yeniden üretimde yansıtmaktan çok biçimlendirme, yeniden inşa etme, müdahale etme eylemi olduğu en başta kabul edilmelidir. Özellikle popüler sinema filmleri söz konusu olduğunda bu ilişkiler ă̆ı daha belirgin olarak karşımıza çıkmaktadır.

Bu çalışmada, öncelikle toplumsal bellek, tarih, ideoloji ve sinema ilişkisi kuramsal olarak tartışılacaktır. İkinci kısımda ise son dönemde yükselişe geçen popüler Türk sineması içinde yer alan ve gösterime girdiği yıl izleyici rekoru kıran, aynı zamanda tüm zamanların en çok izlenen Türk filmleri arasında yer alan Fetih 1453 filmi toplumsal bellek, sinema-tarih ilişkisi bağlamında teorik çerçevede tartışılacaktır.

Anahtar Kelimeler: Toplumsal bellek, sinema, Fetih 1453

\footnotetext{
* Dr. Öğr. Üyesi, Selçuk Üniversitesi İletişim Fakültesi ORCID ID 0000-0002-4150-4796 Makale Gönderim Tarihi: 06.03.2019- Makale Kabul Tarihi: 08.05.2019
} 


\title{
SOCIAL MEMORY AND CINEMA: FETIH 1453 AS AN EXAMPLE OF POPULAR FILM
}

\begin{abstract}
Social Memory can be defined as "community's familiarity to their past events and those events' consequences, an ability to look back in time flow in a historical period". Social memory is not a repository where historical data is stored and is retrieved when needed. Social memory has been said to be an arena, a political process in itself, and an important framework for the construction of national identity and history. From this perspective, social memory can be seen as a directed and reconstructed phenomenon.
\end{abstract}

Arts, mass media and civil society play an important role in reconstructing the memory while cinema has the same role especially on narrative formation and context setting. It must be accepted in the first place that cinema which reproduces the real world through representations, is an act of shaping, reconstructing, interfering rather than reflecting this reproduction. Especially in the case of popular films, this network of relationships emerges more prominently.

Firstly, the relationship among social memory, history, ideology and cinema will be discussed theoretically in this study. In the second part, the film Fetih 1453 which was a blockbuster film in the year it was released and is still among the most popular Turkish films in the popular Turkish cinema will be examined. Fetih 1453, the most popular film in its field of Turkish cinema history, will be discussed within the context of social memory, cinema-history relation and popular cinema concepts.

Keywords: Social memory, cinema, Fetih 1453 


\section{GíRiş}

Farklı disiplinlerde farklı çalışmalarla ele alınan toplumsal bellek kavramının, güncel kullanımı The Elementary Forms of Religious Life'ta Emile Durkheim'a ve onun öğrencisi olan Maurice Halbwachs'un 1925 tarihli The Social Frameworks of Memory kitabına kadar dayandırılabilir (Olick 2014: 178). Halbwachs büyük ölçüde Freud'a duyduğu tepki sonucunda kolektif bellek ile tarih arasındaki ayrımı belirginleştirme girişimine gitmiştir. Freud, bireyin bilinçaltının tüm geçmiş deneyimlerin depolandığ1 yer olduğunu ileri sürmüştür. Freud'da hatırlamadan ziyade, unutma merkezdedir ve bastırma ya da "perde" hatıralarla ikame edilmesi yoluyla rahatsız edici hatıralara erişimi engelleyen unutmadır. Freud'un aksine, Halbwachs belleğin hiçbir şekilde tüm geçmiş deneyimlerin depolandığı yer olamayacağını ileri sürmektedir (Olick 2014:180).

Belleğin sosyal koşullara bağlılığını vurgulayan Halbwachs, belleği biyolojik açıdan, yani nöroloji ve beyin fizyolojisi açısından ele almamakta, bunun yerine bireysel bir belleğin oluşması ve korunması için şart olan sosyal çerçeveyi koymaktadır. Yani, bellek insanın sosyalizasyon sürecinde oluşmaktadır. Bireyler, anılarını bir toplumsal gruba üyelikleri yoluyla, özellikle akrabalık, dinsel ve sınıfsal bağlantılar yoluyla edinebilmekte ve anımsayabilmektedirler. Bellek her ne kadar bir bireye "ait" olsa da, toplumsal olarak belirlenmektedir. Bu yüzden “toplumsal bellek" mecazi bir ifade olarak alg1lanmamalıdır (Assmann 2001: 3840). Buna göre bellek sadece bireyin anılarına dayanmamakta; aynı zamanda ortak yaşanmışlıklarında bir araya gelmesiyle oluşmaktadır. Dolayısıyla bellek aslında büyük ölçüde toplumsal olarak inşa edilmekte ve hatırlama edimi bireyin özelliklerinden, bakış açısından etkilense dahi toplumsal etkiler ağır basmaktadır. Toplumsal bellek "en iyi biçimde tarihin yeniden kurulması" olarak adlandırılabilir (Connerton 1999: 27). Ne kadar kişisel olursa olsun, her bellek yoklama işi, başka birçok kimsenin de sahip olduğu bir düşünceler kümesiyle ilişki içinde olmakta, 
yani bir parçası olduğumuz toplumların maddi ve manevi tüm yaşamlarıyla birlikte gerçekleşmektedir (Connerton 1999: 65-66)

Nora'ya göre, hafıza canlıdır ve yaşadığı toplum içinde doğmaktadır. Bellek, sürekli değişmekte, manipüle edilmekte, dönem dönem canlanmakta ve hem hatırlama hem de unutma deformasyona uğramaktadır (Nora 1989: 8). Yeniden kurma işlemine dayanan hafızada, geçmiş, şimdiki zamanın değişken ilişkileri çerçevesinde sürekli olarak yeniden örgütlenmekte, hafıza, sadece geçmişi kurgulamakla kalmayıp, aynı zamanda şimdinin ve geleceğin deneyimlerini de organize etmektedir (Sancar 2016: 42-43).

Halbwachs, birbiriyle dönüşümlü kullanılabilecek şekilde otobiyografik bellek, tarihsel bellek, tarih ve kolektif bellek kavramlarından bahsetmektedir. Otobiyografik bellek, kendi yaşadığımız olaylara ilişkin bellek, tarihsel bellek ise bize sadece tarih kayıtlarından ulaşan bellektir. Tarih, organik bir ilişkimizin kalmadığı geçmiş iken, kolektif bellek, kimliğimizi şekillendiren faal bir geçmiştir (Olick 2014:180).

Bu bağlamda bakıldığında hatırlama edimi birey tarafından gerçekleşse de bellek toplumsal çerçeve içinde şekillenmekte ve toplumsal bellek söz konusu olduğunda bireysel özellikler ve toplumsal etkiler bir arada işlev göstermektedir. Bu çalışmada toplumsal belleğin inşa sürecinde popüler sinemanın etkilerini ortaya koymak amaçlanmaktadır. Bu doğrultuda öncelikle bellek ve belleğe dair kavramlar ele alınmış, sonrasında sinema-toplumsal bellek ilişkisine değinilmiştir. Son olarak da 2012 yapımı Faruk Aksoy'un yönettiği Fetih 1453 filmi incelenmiştir. Yaklaşık olarak 6,5 milyon seyirciye ulaşan ve 18 milyon dolarlık bütçeye sahip olan film üretilen en pahalı yapım olarak Türk sinemasında tarihsel filmler arasındaki yerini almaktadır. Film aynı zamanda tüm zamanların en çok izlenen ilk 10 Türk filmi arasındaki tek tarihi filmdir. Çalışma, bu örnek üzerinden popüler sinema toplumsal bellek ilişkisini teorik çerçevede ele almaktadır. 


\section{KAVRAMSAL ÇERÇEVE}

\subsection{Toplumsal Bellek: Kolektif, Tarihsel, Kültürel Bellek}

Bellek, "tarihin sosyal olarak kendimize uygun bir hale getirilmesi" anlamını taşımakta ve geçmişi "anda hakim olunabilir ve kavranabilir kılan bir inanç ve temsiller ă̆ını harekete geçirmektedir". (Bilgin 2013: 14).

Bugünkü kimliğimizle geçmişe dönüp bakarken, şimdiki konumumuza ters düşmeyecek, rahatsızlık yaratmayacak deneyimler aranmaktadır. Phillips, bu görüşten hareketle hatırlamayı "Hatırlama, bir yeniden tanımlama sürecidir, geçmiş yeniden yapılır, bellek geçmişi icat etmenin bir yoludur" şeklinde yorumlamaktadır (Akt. Göle 2007: 25-27).

Kolektif belleği “bir grup'un grup üyeleri tarafindan ortak olarak paylaşılan ve grup kimliğini biçimlendiren aktif geçmişi” olarak tanımlamak mümkündür (Bilgin,2013,73). Anılar bireysel belleklerde kendine has bir bicimde yer etse bile toplumsal ve kültürel niteliklerini yitirmemektedirler (Schudson 2007: 180). Kolektif bellek, aile ya da ulus gibi farklı ilgi ve motivasyonlara sahip herhangi bir sosyal grubu birleştiren ortak bir kimliği sağlamaktadır. Her toplum geçmişe dair imajlar oluşturmakta, bu geçmiş, duyguları yönetme, insanları eyleme geçirme, kısaca, sosyo-kültürel bir eylem modu olarak karşımıza çıkmaktadır (Confino 1997: 1390).

Kolektif bellek, toplumsal olarak inşa edilmiş bir kavram olarak değerlendirilmektedir. Bu açıdan bakıldığında, kolektif bellek insanların dünyayı anlamlandırmasına aracılık eden sembolik çerçeveler ve anlamlar sağlayarak bugünün gerçekliğini de şekillendirmektedir (Bilgin 2013: 73). Bu açıdan tarih ve bellek kavramları birbirinden farklı anlamları olan kavramlar olarak düşünülmelidir.

Norvick'e göre ise, kolektif bellek olayları basitleştirmekte, tek bir bakış açısından görmekte ve olayları efsanevi arketiplere indirgemektedir. Tarih ve kolektif bellek 
ayrımıyla ilgili kendi görüşünü geliştirirken, kolektif belleğin "gerçek anlamda tarihdışı, hatta tarih karşıtı olduğunu" söyleyen Norvick, tarihin doğası gereği olayların şimdi değil de o zaman gerçekleşmiş olmasına, şimdikinden farklı koşullarda doğmuş olmasına odaklandığını dile getirmekte, belleğin ise gerçek anlamda tarihdışı, hatta tarih karşıtı olduğunu belirtmektedir (akt Wertsch 2015: 159-160).

Pierre Nora'da bellek ve tarihin eş anlamlı olmadığına vurgu yapmaktadır. "Hafiza, her zaman güncel bir olay, sürekli şimdiki zamanda yaşanan bir bağ iken, tarih, geçmişin bir tasavourudur." Bellek, hatıraları kutsallaştırırken tarih hatırayı dışarıda bırakmaktadır. Bellek kaynağını bir gruptan almakta, buna karşın tarih ya herkesin malı ya da kimseye ait olmayan bir öğe olarak değerlendirilmektedir (Nora 2006: 19).

Tarih geçmişin doğru bir dökümünü vermeye çalışırken, buna karşılık, kolektif hatırlamada geçmiş genellikle bugünle bağlantılıdır; bireyin kendi kimliği ve grubun kimliği, toplumun şanlı tarihiyle desteklenmektedir. Kolektif bellekte, geçmişimizin olumsuz yönleri çıarılmakta veya görmezden gelinmektedir (Roediger ve ark 2015: 178). Kolektif bellek geçmişi bugünle ilişkilendirip, sorgulanmayan kahramanlık hikayeleri ortaya koyarken tarih, geçmişi bugünden ayırıp, süregiden tarihi yorumlamaktadır (Wertsch 2015: 162). Kolektif bellek bireysel hatıraların toplamıdır. Bu nedenle kolektif bellek hayâli anılarda, kişisel şahitliklerde, sözlü tarihte, gelenekte, mitte, üslupta, dilde, sanatta, popüler kültürde ve insan eliyle inşa edilmiş dünyada bulunmaktadır(Olick 2014: 181).

Tarihsel bellek ise geçmişin bilim adamı tarzında yeniden inşası, geçmiş yaşamların çevrede bıraktıkları izlerin sistematik analizidir. Kolektif bellek bu izlerin nesillere iletilmesidir. Tarihsel bellek bir yandan geçmişin anılarını kırarak inşa olurken bir yandan da geçmişe bakışımızda devreye girmektedir. Tarihsel üretim zamanla kültürel mirasa katılmakta, karşılıklı bir değişim dönüşüm geçirmektedirler. Tarihsel bellek bir iz haline geldiğinde kolektif bellekte yer 
bulmaktadır. Bu açıdan ikisi birbirinden bağımsız değildir. Bilgin, tarihin kolektif bellekten en önemli farkının, ortaya koyduğu ürünün niteliğinden ziyade hareket tarzında olduğunu vurgulamaktadır. Ayrıca, tarihçinin anlatısında "biz"in olmadı̆̆ını oysa kollektif belleğin anlatısının, bir aidiyet formatına göre yazılmak zorunda olduğu noktasına da değinmektedir (Bilgin 2013: 28-29).

Assmann ise toplumsal hatırlamaya ilişkin iki bellek türüne işaret eder. İletişimsel ve kültürel bellek. İletişimsel bellek yakın geçmişe ilişkin anıları kapsar(Assmann 2001: 53-54). Bunlar kişinin çağdaşları ile paylaştığı anılardır. Kısa dönemli, nesilsel ve bireysel bellekle ilgilidir (West 2011: 104). Gündelik olmayan olayları hatırlama organı olan kültürel bellek ise geçmişin belli noktalarına odaklanmakta ve daha çok anının ilişkide olduğu sembolik figürlerde yoğunlaşmaktadır (Assmann 2001: 55). Kültürel belleği kolektif belleğin bir şekli olarak değerlendiren Assmann'a göre, kültürel bellek bir konumdan diğerine bir nesilden öbürüne aktarılabilen sembolik formdur. Şarkılar, danslar, anlatılar, ritüeller vb. semboller aracılığıyla var olan kültürel bellek, kendilerine bilgiyi taşıma yetkisi tanınan özel taşıyıcılar, öğretmenler, yazarlar, filozoflar vb., tarafından aktarılmaktadır (Assmann 2008: 110-113).

Sturken, kültürel belleği, "kültürel anlamlar ve kültürel ürünlerle doldurulmuş resmi tarih söyleminin dışında paylaşılan hafıza" olarak tanımlamaktadır ( Akt. Meusburger 2011: 52). Kültürel bellek için gerçek değil hatırlanan tarih önemlidir. Tarihsel anılar üzerinden zaman geçtiğinde, yeniden yorumlanmakta ve kültürün gereksinimlerine karşılık verecek şekilde değiştirilmekte, ödenen bedeller unutulup olumlu sonuçlar üzerinde duruldukça, anılar genellikle efsanevi bir nitelik kazanmaktadır (Pennebaker ve Gonzales 2015: 238). Yani gerçek tarih zamanla hatırlanan tarihe ve ardından da efsaneye dönüşmektedir. Bu anlamda kültürel belleğin içeriğini ulaşılmaz geçmişte yaşananlar oluşturmakta, geleneksel sembolik sahnelemeler aracılığıyla aktarılmakta ve efsanevi geçmiş zamanı anlatmaktadır (Assmann 2001: 59). 
Hatırlama, gerçekte olan olayları değil, bir öykü haline getirilmiş olayları referans almakta, anlam üretimiyle ele ele gitmektedir. Geçmiş, öyküleme, belgeleme ve yorumlama yoluyla gerçekleşen toplumsal inşanın bir ürünü olarak varlık kazanmaktadır. Bu durum, toplumsal hafızanın gruba özgü oluşumunun önemli bir sonucudur. Halbwachs'a göre, hiçbir hafıza, geçmişi olduğu gibi koruyamamaktadır. Ondan geriye grubun "her dönemde kendi bağlamına özgü olarak yeniden kurabildiği biçimi" kalmaktadır (Sancar 2016: 41-43).

Geçmişi anımsamanın ve geçmiş hakkında yazmanın eskiden masum bir eylem olarak kabul edildiğini vurgulayan Peter Burke'e göre, artık ne anılar ne de geçmişi anlatan kayıtlar nesnel kabul edilmektedir. Yorumlar ve çarpitma toplumsal olarak koşullandırılmıştır Toplumsal, tarihi ve psikolojik etkenlerden bağımsız olmayan belleği, "bir bilgi kodlama, bilgi depolama ve bilgiyi stratejik biçimde bulup getirme sürecidir." şeklinde tanımlamayan Schudson'a göre, kolektif bellekte dört tane önemli ve ayırt edilebilir çarpıtma surecinden söz etmek mümkündür. Bunlar, uzaklaştırma, araçsallaştırma, öyküleştirme ve uzlaşımsallaştırmadır (Schudson 2007: 181). Geçmişin geri çekilme süreci olan uzaklaştırmada, zamanın akışının belleği yeniden biçimlendirdiği vurgulanmaktadır. Öncelikle geçmişe özgü ayrıntılar yitirilmekte ve anılar silikleştirilerek belirsizleştirilmektedir. Araçsallaştırma da ise, bellek, seçerken ve tahrif ederken güncel çıkarlara hizmet eder. Yani anılar, güncel bir stratejik amacı desteklemeye yardımcı olmak için hatırlanıp biçimlendirilebilir. Öyküleme sadece geçmişte olan olayları aktarma değil, aynı zamanda süsleme ve ilginç hale getirmedir. Öyküleme, anlatılan olayı basitleştirir. Söz konusu biçim genellikle giriş, gelişme ve sonuç bölümü olan bir anlatı inşa eder. Bir kahraman, karşısına çıkan engeller ve bu engelleri aşma çabaları anlatılmalıdır. Bilişselleştirme ve uzlaşımsallaştırmada ise, geçmişin bilinebilir hale getirilmesinde, kültürel açıdan değer verilen ve düzenli olarak kutlanan eylemleri anımsamanın önemi vurgulanmaktadır (Schudson 2007: 182-195). 
Genel olarak bakıldığında kimi zaman birbirinin yerine kullanılan ancak aralarında farklar bulunan bu kavramlar toplumsal bellek kavramının bileşenlerini oluşturmaktadır ve kavram politik ve toplumsal dönüşümlerin güçlü bir sembolü haline gelmiş durumdadır. Bu oluşum sürecine etki eden en önemli araçlardan biri de sinemadır.

\subsection{Sinema ve Bellek}

Belleğin kimi zaman, bayramlar, anitlar, törenler, sözlükler, müzeler, halk sanatları, gelenekler, aile albümleri gibi unsurlarda somutlaştı̆̆ını kimi zamanda soy, ırk, din gibi düşünsel olarak oluşturulmuş soyut mekânlar aracılığıyla aktarıldığını vurgulayan Nora, bu mekanları hafıza mekanları olarak adlandırmaktadır. Buna göre hafızanın oluştuğu ve taşındığı her alan hafıza mekânı olarak değerlendirilmektedir (Nora 2006: 9-14). Nora'nın ifadesiyle hafıza mekanları, bize sadece unutmak istediğimiz geçmişimizi hatırlatmaz, aynı zamanda gurur duyduğumuz ya da duyacağımız; geçmişimizi anımsatmak için vardır ve toplumsal belleğimizin canlı tutulmasına aracılık ederler (Nora 2006: 23).

Bu bağlamda medya da hafıza mekânları olarak değerlendirilebilmektedir. Kitle iletişim araçları kolektif belleğin yalnızca kaydedildiği ya da iletildiği mekânlar değil, aynı zamanda belleğin kurgulandığı ve yeniden inşa edildiği ortamlar olarak da işlev görmektedirler. Günümüzde hafıza ve tarih arasındaki sınırların kalkmaya başladığını belirten Nora (2006: 38) tarih-hafıza ve hafıza-kurgunun ilişki içinde olduğu bir tür tarihin doğduğunu ifade etmektedir.

Belleği çelişkili bir deneyim, bazı durumları kapsama alanı dışında bırakan daha çok şimdiki zamandan geçmişin görünümü, bir montaj olarak değerlendiren Hoskins'e göre de medya, bu sürece sıklıkla bir dünya görüşü inşa etme şeklinde müdahale etmektedir (Hoskins 2004: 109). Medya olayları topluma aktararak kültürel belleği inşa etmekte, kolektif bellek ise büyük ölçüde bu kültürel bellek üzerinden inşa edilmektedir. Bu bağlamda, kolektif belleğin en altta yer aldığı, tarihsel ve kültürel bellek ile deneyimler aracılığıyla şekillendiği 
söylenebilmektedir (İnce 2010:15). Bir topluluğun ortak deneyimlerine dayalı olarak oluşan kolektif bellek kültürel metin ve unsurlar üzerinden geleceğe aktarılmakta medya bir hafıza mekânı olarak hem kolektif belleğin taşındığı hem de iktidar ve sermayenin yönlendirmesiyle inşa edilen bir ortam olarak öne çıkmaktadır (Başlar 2018: 171). Andrea Huyysen (1999: 61)'in de belirttiği gibi anlatıda, görüntüde ya da kaydedilmiş seste olsun, bütün temsil biçimleri belleğe dayanmaktadır. Çünkü birey hayat hikayesini bir anlatı olarak kurarken bunlara yeni deneyimler ekleyebilmekte, anımsadıklarını unutabilmekte, kimi zaman unuttuklarını hatırlayabilmekte, değiştirebilmekte ya da hiç yaşanmamışları ekleyebilmektedir. Yaşananlar kadar yaşanmayanlarda benliğimizin bir parçası haline gelmekte ve anlatı içine yerini almaktadır (Göle 2007:27).

Roberto Rosselini'nin “Filmler tarih yazımında diğerleri kadar, belki de diğerlerinden daha değerli araçlar olmalıdır." cümlesiyle belirttiği gibi kamerayı tutan eli ve onu yöneten göz ile beyni düşünecek olursak, tarihçi olarak asıl sinemacılardan söz etmek gerekmektedir (Burke 2016: 179). Bu açıdan bakıldığında ilk yıllarından itibaren tarihle ilgili olan sinema geçmişe ilişkin belleğimizde birçok görüntü oluşturmaktadır. Bu nedenle filmler bir yandan kendileri tarih araştırmaları için birer kaynağa dönüşebilirken, bir yandan da tarihin yeniden inşasında rol oynayabilmektedirler.

Anlatısını hem iletişimsel belleğe, hem de kültürel belleğe dayalı olarak kuran sinema, belgeseller ve otobiyografik kurmacalar gibi sözlü tarih yöntemini kullanan filmlerle iletişimsel belleğe bağlı olarak kurgulanmaktadır. Bununla birlikte, sinema kültürel belleğin de en önemli taşıyıcılarından hatta kurucularından kabul edilebilir (Erkılıç 2012: 60-61).

McAdams (Akt. Göle 2007: 27), hayatı gerçek olgulardan çok, anlatının şekillendirdiğini öne sürmekte ve hayatın, öznel ve süslenmiş bir anlatı aracılı̆̆ılyla kurulduğunu vurgulamaktadır. Bu anlatının inşası sırasında var olanlara yeni deneyimlerin katılabileceği, bazılarının unutabileceği, bellekte kalanların 
değişebileceği ya da asla yaşanmamışların eklenebileceğini ifade etmektedir. Bu noktadan bakıldığında geçmiş, şimdinin çıkarlarıyla uyumlu olarak sürekli bir yeniden yapılanma içindedir. Bu anlamda bellek geçmişi, bir toplumun bireylerinin amaçlarına uygun olarak düzenlemekte, bu amaçları haklı çıkarma işlevini üstlenmektedir. Güncel fikirlere, değerlere, inançlara ters düşen geçmiş ya kolektif bellekten silinmekte ya da değişime uğramakta, yeni bilgiler ve siyasal değişimlerin ışığında tarih gözden geçirilmektedir. Mead'in ifadesiyle "her kuşak kendi tarihini yazmaktadır" ve toplumsal bellek de bir kurgudur (Akt.Göle 2007: 28).

Bu noktada, bir anlatı türü olan sinema ve bellek ilişkisi önem kazanmaktadır. Gücünü, izleyiciye olaylara tanık olduğu hissini vermesinden alan sinema, aynı zamanda tam da bu nedenden dolayı büyük bir tehlikeyi içinde barındırmaktadır. Çünkü yaratmış olduğu bu tanıklık hissi aslında bir yanılsamadır. Göze görünmeyen yönetmen bu deneyimi şekillendirmekte ve gerçekte ne olduğuna değil, sinematografik bir biçime sahip ve pek çok izleyiciye birden hitap edecek bir öykü anlatmaya odaklanmaktadır. Bu durumda en önemli nokta, "filme çekilmiş tarihin, tıpkı resimlenmiş veya yazılmış tarih gibi, bir yorumlama eylemi oluşu" olduğudur (Burke 2016:180). Jean Claude Carrier'in de belirttiği gibi, sinema geçmişi yeniden ortaya çıkarmakta, kumaşlarından giysilerine kadar insanların jestlerinden dillerine kadar her şeyi yeniden yaratmaktadır (Akt. Makal 2014: 15).

Tarihi filmlerin geçmişi yeniden inşa ettiğini vurgulayan Rosenstone, filmlerin kendi anlatım kodlarıyla bir geçmiş temsili oluşturduklarını ifade etmektedir. Bu nedenle sinema ve tarih arasındaki ilişkide asıl sorgulanması gereken noktanın, anlatı içinde tarihin hangi parçasının seçildiği, filmlerin tarihsel bir dünyayı nasıl yarattığ1 ve sunduğu, geçmişi canlandıran, kodlar ve duyguların kurgu ve dramaya uygun olarak nasıl gösterildiği sorularıdır (Rosenstone 1995b: 3-4).

$\mathrm{Bu}$ anlamda tarihi filmler geçmişin sadece bir görünümünü sunmamakta aynı zamanda bugünün, geçmiş üzerine olan görüşlerinin bir yansıması olarak da okunabilmektedir. Kimi zaman tarihi kullanarak geçmiş üzerine bir önerme 
getirme amacıyla bu durum kullanılabilmektedir. Tarihin sinema aracılı̆̆ıla yeniden inşası söz konusu olduğunda, dönemin siyasi anlayışı ve ideolojide belirleyici olarak ortaya çıkmaktadır. Tarih aracılığıyla topluma "kim oldukları, nereden geldikleri" gibi sorular cevaplar ile hatırlatılmakta, toplumu yönlendirmede tarihe göndermede bulunarak bir takım görüşler temsiller yoluyla aktarılmaktadır. Bu açıdan tek bir bakışın hakim olmadığı düşünülürse sinema, bir yandan ideolojik bir yeniden üretim aracı olarak resmi tarih söylemlerine eklemlenmekte diğer yandan ise sorgulama ve alternatif tarih arayışlarına da öncülük etmektedir (Erkılıç, 2012, 25-26).

Ferro (2017: 157) tarih ile bağlantılı olarak filmlerin sınıflandırmasını, toplum üzerine söylemleri odağına alarak yapmaktadır. Bu sınıflandırma; baskın kurum ya da ideolojiler, karşı tarih ya da çözümleme oluşturanlar ile ona muhalifler, sözlü gelenek ya da sanat yapıtı ile ayakta kalmış toplumsal ya da tarihsel bellek ve bilimsel olsun ya da olmasın bağımsız yorumlamalar olarak üçe ayrılmaktadır. Bu ayrımlamada hakim ideoloji ve ona muhalefet gösterenlerin yanı sıra bağımsız yorumlama yapanlara da yer verilmektedir.

Sinema ve tarih ilişkisine genel olarak bakıldığında, kendilerine has özelliklerini ve amaçlarını daha etkili ortaya koymak için birbirlerinden yararlandıkları görülmektedir. Sinema tarih ilişkisinde, sinemanın tarihe başvurma nedenleri arasında öncelikle, kahraman, çatışma gibi hazır dramatik öğelerin tarihte yer alması, kostüm, dekor gibi görsel zenginlik sunan öğelerin sinematografik kullanımı yer almaktadır. Ayrıca gişe başarısı elde etmek, star olgusu bağlamında tarihsel karakterlerin ünlü oyuncular tarafından canlandırılmasının ilgi çekmesi ve önemli tarihsel olayların ilgi görmesi, çekildiği döneme ilişkin tarih dolayımıyla sakıncalı görülmeden fikir beyan etme özgürlüğünü elde edebilmek temel nedenler arasında sıralanabilmektedir. Tarihin sinemaya başvurma nedenleri ise, görsel verileri tarih yazımında belge olarak kullanabilmek ve görsel belleğin oluşturulması, görsel materyallerle tarih öğrenimi yapabilmek ve son olarak 
kollektif bellek oluşumuna katkıda bulunan sinema yoluyla resmi tarih anlatısını güçlendirmek şeklinde sıralanabilmektedir (Erkılıç 2012: 26-27).

Görüldüğü gibi sinema ve tarih karşllıklı olarak birbirlerine gereksinim duymaktadırlar. Ancak tarihsel filmlerin genellikle ele aldığı konuyu yeterince sorgulamadığı, olguları yüzeysel biçimde yansıttı̆̆ı, ticariliğin getirdiği bazı sorunlarında bu duruma neden olduğu söylenebilmektedir. Bu anlamda sinemanın belleğin oluşumuna kendi varoluşsal problemleriyle katkı sağladığı ifade edilebilir.

\subsection{Sonrası Türk Sinemasında Tarih ve Bellek}

Tarihsel filmler, konusunu tarihi olaylardan ya da kişilerden alan filmlerdir. Tarihsel filmlerin amac1, dünün gerçeğini yansıtmaktır. Ancak sinema endüstrisinin yapısından kaynaklanan nedenler bu türü, çoğunlukla bu amacından uzaklaştırıp, hatta ters düşürmektedir. Tarihsel türde çevrilmiş filmlerin çoğu, tarihsel gerçeklere hiç uymayan, yalnızca adları tarihten alınmış birtakım kişilerin serüvenleri kılığında perdeye yansımıştır. Oysa ki tarihsel filmler konusunu tarihten aldığı için gerçeklerle uyumlu olması ve olaylara nesnel bir yaklaşım sunması beklenir. Ancak kurmaca dünyanın doğasından dolayı tam anlamıla bir belgesel gibi gerçekçi anlayışta olması da beklenemez (Özön 1972: 131).

Tarihsel filmin kendi içinde "çağ ve giysili film" olarak iki alt türü olduğunu vurgulayan Özön'e göre, çağ filmi, “belli bir çağı bütün toplumsal, siyasal, kültürel yönleriyle canlandıran, uygarlık değerlerini yansıtan" filmlerdir. İkincisi, "geçmiş bir toplumun belli bir tarihteki yaşayışını, daha çok dış görünüşü, özellikle giysilere önem vererek yansıtan filmdir". Özön'ün giysili film olarak adlandırdığı bu tür genellikle tarihi kostüme filmler olarak da adlandırılmaktadır (1972: 132). Bu tür filmler Türk sinema tarihinde dönem dönem ön plana çıkan türler arasında olmuşlardır. 
Gürata, bu filmlerde tarihsel ve coğrafi ortam belirli oranlarda farklılık gösterse de olay örgüsü, temel motifler ve karakterlerin, türün temel ortak özellikleri olduğunu belirtmektedir. Bu filmler, ele aldığı tarihsel dönemi, mizansenin (dekor, giysiler ve aksesuarlar) yanı sıra, söylem aracılığıyla da karikatürize etmektedir (Gürata 2007: 44-45).

Türün ulusal kimlik oluşturulmasında önemli bir yerde durduğunu belirten İspi'ye göre, kimliği tanımlanırken biz ve öteki ayrımlarında öteki kötü olarak inşa edilir. "Biz" kahramanlık, zeka, erkeklik vurgularıyla temsil edilmektedir (İspi 2007: 58). Bu anlamda bütün taraflar için “öteki” yaratma çabası bir "eksikliği tatmin" etme, olmayan şeyin üzerine gitme ile ilişkili olarak değerlendirilebilir (İspi 2007: 63). Elbette bu gibi filmlerde izlenenler doğrudan tarihsel olgu olarak algılanıp kabullenilmese de zihinlerde geçmişe ilişkin imgelerin ve tarihsel bilgilerin oluşmasında etkili olmaktadır. Milliyetçilik, siyaset, teknoloji ve toplumsal dönüşümün kesişme noktalarında şekillenmekte, popüler kültür ve onun kitlelere doğrudan nüfuz eden araçlarından biri olan sinema, "yeni milliyetçiliğin" oluşumunda etkili olmaktadır (Güney 2006: 213). Özellikle Yeşilçam sinemasında aynı konuların defalarca işlenmesi, tekrarlarının çekilmesi sadece konuların sığlığı, senaristlerin beceriksizliği ile açıklanamamaktadır. Bu filmlerde kullanılan son derece basit mesaj yüklü diyaloglar ve temsil stratejileri, sıradan insanların üzerinde büyük etki yaratmakta ve 1960 sonrası tohumları atılıp, zamanla gelişen gayriresmi milliyetçiliğin tutunmasında ve yaygınlaşmasında büyük önem taşımaktadır. $\mathrm{Bu}$ tür filmler genellikle rasyonellikten uzak, toplumun genel durumunu vermekten yoksun filmler olarak eleştirilse de milliyetçilik de zaten böylesi akıldışı yol ve yordamlar aracılığıyla, akıldışı halk öyküleri, idealize edilmiş düşman kişi/grup ya da kültürler üzerinden popüler kültür aracılığıyla yayılmaktadır. Popüler kültürün önemli bir aracı olan sinema bu dönemde böylesi bir işlev görmektedir (Güney 2006: 216). 
Tarihi filmlerin hangi dönemde olursa olsun milliyetçi bir söylem taşıyacağını ve “öteki” kim olursa olsun nedenli nedensiz Türk düşmanı olacağını ifade eden Scognamillo ve Demirhan (1999: 135) bu bağlamda gerçekler ve gerçeklere dayanan tarihi yorumlar aramanın gereksiz olduğunu belirtmektedir. Bu filmler sadece kahramanlık gösterileriyle seyircide katharsis yaratmakla kalmamış, özellikle, 70'lerde ülkenin içinde bulunduğu toplumsal ve siyasi süreç ile de seyircide karşılık bulmuştur. Türün önemli örnekler verdiği yılların aynı zamanda milliyetçiliğin yükseldiği ve özellikle Yunanistan'la olan egemenlik ve kıta sahanlığı gibi sorunlar hakkında gerginliğin arttı̆̆ı yıllara denk gelmesi dikkat çekicidir (Gürata 2007: 53). Bu bağlamda sinemanın var olan siyasi atmosferden yararlandığı görülmektedir. Bayrı'da popüler kültür ürünlerinde özellikle de sinemada yansıyan Bizans imajının; Yunanlılar ve Yunanistan ile bağlantılı olmasına dikkat çekmektedir. Bu dönemde çekilen tarihi filmlerde özellikle kostüme avantür filmlerde "öteki”, zalim, zengin, şehirli ve bunların sembolü olan Bizans' iken, "biz" $i$ ise fakir, mazlum ve bunların sembolü olarak Türk oluşturmaktadır. Bu filmlerde vatan, millet, şehit ve bayrak kelimeleri bolca telaffuz edilmektedir (Bayrı 2013: 78-80). “Bizim tarihimiz" ile “başkalarının tarihi" arasında keskin bir ayrımın yapıldığı bu filmlerde "bizim tarihimiz" hemen hemen hiçbir zaman geçmişin yabancılığını ve garipliğini benimsememekte, “geçmişimiz" mesafeli bir bakışla ele alınmamaktadır (Gürata 2009: 114-115).

Sol eğilimli gazetelerde çizgi roman olarak başlayan kostümlü macera türünün de MC hükümetinin kurulduğu ve MHP'nin yükseldiği 1970'lerde bambaşka bir gelişim çizgisine girdiği görülmektedir. Kıbrıs olayları ile alevlenen milliyetçilik, Türklerin yiğitliği, cengâverliği ve dindarlığı üzerine kurulmuş bir milliyetçilik anlayışıyla beslenmiştir. Ancak kostümlü macera filmlerinin milliyetçi ideolojiyi yaygınlaştırmak üzere çekildiklerini iddia etmek, gerçeği tam olarak yansıtmayacaktır. Bu anlayışın izleri hem toplumda hem de ticari kaygılarla çekilen filmlerin doğasında aranmalıdır (Erkılıç 2012: 110). Kafadar'da elde 
yeterince veri olmamasından dolayı alımlama açısından bu tür bir değerlendirme yapmanın zorluğuna dikkat çekerken yine de bu filmlerin sayısının ve popülaritesinin arttığı dönemlerin, genelde çatışma dönemleri olmasının da altını çizmektedir (Gürata-Kafadar röportaj, 2009: 125).

1990'lar Türkiye'sinde ise toplumsal bellek, tarih ve sinema alanında birbirine zıt iki eğilimin bir arada yaşandığı görülmektedir. Bir yandan yükselen nostalji kültürü diğer yanda ise toplumsal bellek kaybı (Suner 2006: 25). Nostalji kültürü sinemanın popüler kanadı ile ilerlerken toplumsal bellek kaybı ise bağımsız sinemanın ele aldığı konular arasında yer almaktadır. Bellek, travma ve kimlik kavramlarını tartışan bağımsız sinema, azınlık hafızaları ve kimlik bağlamında bir takım hikayeleri perdeye yansıtmaktadır.

Jameson'un geçmişi kullanmada sinemada bir alttür gibi gördüğü nostalji sineması ise kendi şimdiki zamanını tümüyle yadsıyıp, daha eski bir dönemin kayıp gerçekliğini yakalamaya ve yeniden kurmaya çalışmaktadır (Akt. Büyükdüvenci ve Öztürk 2014: 26). İspi'nin ifadesiyle “Bugün, buradasından memnun olmayan bir toplumun gelecekten pek fazla beklentisi olmayınca geçmişe dönmesi (nostalji) ve geçmişini kelimenin tam anlamıla 'fantastikleştirmesi' son derce doğal bir süreç"tir (İspi 2007: 61). Türk sinemasının nostalji filmleri, anlattıkları zaman dilimine o günün değil, bugünün gözüyle bakmakta, izleyiciye bugünün penceresinden bir görünüş sunmaktadır (Suner 2006: 51). Bu filmleri, geçmişi ve kimi zaman geçmişteki siyasal olayları konu edinmelerine karşın, "tarihsel film" diye adlandırmanın yerinde olmayacağını belirten Suner, filmlerin tarih anlatısı içinde öne çıkan olayların dışarıdan ve nesnel bir temsilini üretme iddiası taşımadığını ifade etmekte ve öne çıkanın, nostalji duygusuyla bezeli öznel bellek kültürü olduğunu dile getirmektedir (Suner 2006: 49-50).

Erkılıç ise geçmişten günümüze Türk sinemasında tarihe ilişkin farklı yaklaşım ve perspektiflerde çekilen filmleri, üç temel eğilim çerçevesinde toplamaktadır. Bunlardan ilki tarihi yaklaşımda fantastik öğelerin öne çıktı̆̆ filmlerdir. Kesin bir 
zaman diliminden, mekandan, olaydan veya kişiden yola çımayan bu filmlerde, olaylar, kişiler tamamen kurmacadır. Malkoçoğlu, Kara Murat vb. gibi filmlerde tarihi fon üzerine oturtulan filmin ana teması aşk, macera ve kahramanlık öyküleridir. İkincisi tarihi gerçeklerden yola çıkarak çekilen filmlerdir. Zaman, mekan, olay-durum ve çatışma belirgindir ancak yine de gerçek ve kurmaca iç içe geçmiştir. İlkinden ayrılan yanı kurmacanın tarihi gerçekler üzerine inşa edilmesidir. Vurun Kahpeye, İstanbul'un Fethi vb. filmler bu kategoride değerlendirilebilir. Sonuncusu ise tarihe bir savla yaklaşan filmlerdir. Tarihin belli bir kesintisinde yaşanmış gerçek olayları, durumları ve çatışmaları yorumlarken, önermeler getiren, tarihsel bir tez geliştiren filmlerdir. Dokuz Dağın Efesi, Haremde Dört Kadın, Yorgun Savaşçı vb. filmlerde bu son kategoriye örnek teşkil eden filmlerdir (Erkılıç 2012: 83-84).

2000'li yıllarda Türk sinemasının gelişimine paralel olarak bu tür filmler çok para harcanan yapımlar olarak karşımıza çıkmaya başlamıştır. Tarihi filmlerinin temel bileşenleri olan kostüm ve tarih, bu yeni dönemde üzerinde daha çok durulan ve filmin geçtiği dönemi daha iyi yansıtabilmesi için daha çok emek ve para harcanan unsurlar olmuşlardır (Şahin 2014: 68).

Türk sinemasının, yaşadığı her tür gelişime rağmen, 2000'li yıllarda da tarihle olan ilişkisi tıpkı önceki dönemde olduğu gibi iki ana yolda devam etmektedir. Bir taraftan travma anlatıları olarak da nitelenen kimlik, azınlık hafızalarını gündeme getiren bağımsız yapımlar diğer yanda ise popüler filmlerde kendine yer bulan ve özellikle toplumsal açıdan zor dönemlerde hatırlamak istediğimiz tarihsel başarılar ve geçmişe duyulan özlemi gündeme getiren filmler. Faruk Aksoy'un yönettiği 2012 yapımı Fetih 1453 filmi de çalışma kapsamında bu bağlamda incelenecektir. 


\section{FETİH 1453}

\subsection{Filmle Gelen Geçmiş}

Yeniçă̆'ın başlangıcı olarak kabul edilen İstanbul'un fethi Türk sinemasında daha önce iki kez ele alınmıştır. İlk film 1951 yılında Aydın Arakon tarafından çekilen İstanbul'un Fethi filmidir. İkinci film ise ilk filmden farklı olarak İstanbul'un fethini Bizanslıların bakış açısından ele alan 1997 yapımı Kuşatma Altında Aşk filmidir. Yönetmenliğini Ersin Pertan'ın yaptığı film, tarihi açıdan getirdiği farklı bakış açısı ile de ayrıksı bir örnek olarak görülmektedir. İstanbul'un fethi konusu son olarak, Faruk Aksoy'un yönettiği 2012 yapımı Fetih 1453 ile tekrar seyirci ile buluşmuştur. Yaklaşık olarak 6,5 milyon seyirciye ulaşan ve 18 milyon dolarlık bütçeye sahip olan film üretilen en pahalı yapımlardan biri olarak Türk sinemasında tarihsel filmler arasındaki yerini almaktadır. Film aynı zamanda gösterime girdiği dönemde izleyici rekoru kırmış ve halen en çok izlenen ilk beş Türk filmi arasında 4. sırada yer almaktadır. Türk sinemasının en çok izlenen ilk 3 filmi ise komedi filmleridir. Aynı zamanda film en çok izlenen ilk 10 film içindeki tek tarihi filmdir. İlk 10 filmin yine 7'si komedi filmleridir (https://boxofficeturkiye.com, erişim tarihi: 26.12.2018). Komedi filmlerinin izleyici üstünlüğünü elinde bulundurduğu bu sıralamada Fetih 1453'ün yakaladığı başarı bu anlamda dikkat çekicidir.

Kendinden önce çekilmiş İstanbul'un fethi filmlerinden bilgisayar teknolojisinin yardımıyla oluşturulmuş savaş sahneleri ve efektlerle farklılaşan filmde, şiddet unsurlarının yoğunluğu dikkat çekmektedir. Kan, parçalanan bedenler, kopan bacaklar Hollywood tarzı bir anlatımla izleyiciye sunulmaktadır.

Aksoy, filmle ilgili bu tür eleştirilere;

" 'Filmin, savaş kulelerinin yanması, devrilmesi, oklardan korunmak için kalkanların kaldırılması, üzerine hızla gelen bir şeyi savuşturmak için oyuncunun geriye eğilmesi ve bu planın yavaş çekilmesi gibi bazı sahneler, olağanüstü bir zorlamayla Hollywood filmlerinin sahnelerine benzetilmiş' Bu iddialar büyük bir tebessümle okuduk. Bir anlamda çalıntı ve çakma bir film yapmakla itham edilmemiz 
üzerine bu açıklamayı yapmak durumunda kaldık. Seyircimize duydŭ̆umuz saygıdan dolayı bu mesnetsiz iddianın altında kalamazdık. Bu türde yazıların aslında ciddi bir öz güven yoksunluğunun yansıması olduğu ortadadır. Bizim bu filmle yapmaya çalıştığımız şey de tam olarak bu ruh haliyle mücadele etmektir. Bir eser ortaya koyan bir kurum olarak başından itibaren takdirin milletimize ait olduğunu ifade ettim. Milletimiz bu takdiri ortaya koymuş ve sinema salonlarını doldurarak, coşku ve alkışlarla en güzel cevabı vermiştir." şeklinde cevap vermiş, bu eleştirileri özgüven eksikliği olarak yorumlamıştır (http://www0.haberler.com/fetih-1453-filminin-yonetmenielestirileri-3386786-haberi/, erişim tarihi: 5.01.2019)).

Türkiye'de tüm zamanlar seyirci rekoruna bakıldığında Fetih 1453 ilk 5 film arasında bulunmakta ve ilk üçü komedi filmi olan tabloda tek tarihi film olarak 4 . sırada yer almaktadır (https://boxofficeturkiye.com/tumzaman/?tm=1989, erişim tarihi: 26.12.2018). Öztaş vd. tarafından tarihî film veya tarihî dizilerin tarihe ilgiyi artırıp artırmadığına yönelik öğrenci görüşlerini ortaya koymak amacıyla Kırklareli Üniversitesi bünyesindeki Meslek Yüksekokullarında öğrenime devam eden 402 öğrenciye yapılan ankette öğrencilerin yaklaşık üçte birinin Fetih 1453'ü izlediği ve yaklaşık yarısının en beğendiği film olduğu sonucu ortaya çıkmıştır (Öztaş ve ark 2013: 110-111). Fetih 1453 filmi \%31 oranında izlenme payına sahipken buna en yakın oran \%17,9 ile Muhteşem Yüzyıl'dır. Yine en beğendikleri tarihi film ya da diziyi yazmaları istendiğinde \%45 Fetih 1453 cevabını verirken ikinci olan Muhteşem Yüzyıl 12,9 oranında kalmıştır. Araştırma kapsamında katılımcıların belirttiği diğer filmlerden bazıları ise; Spartacus \%6, CengizHan \%3,7, 120 \%3, Çanakkal \%3, Çanakkale Geçilmez \%3, Son Osmanlı Yandım Ali \%2,5' dir. Bu bağlamda araştırma kapsamında, filmin gençler arasında da oldukça popüler olduğu ve sevildiği görülmektedir.

Çakmak ve Cengiz tarafından Fetih 1453 filmi izleyicileri üzerinde gerçekleştirilen araştırma sonuçlarına göre ise, izleyicilerin Fetih 1453 filmini tercih etmelerinde filmin konusu en yüksek paya $(\% 12,70)$ sahip unsur olarak görülmektedir. Bunu 
sırasıyla, fragmanının ilgi çekici olması $(\% 9,80)$, yerli bir yapım olması $(\% 9,60)$, arkadaşların tavsiyesi $(\% 8,60)$ izlemektedir. Fetih 1453 filmi ile ilgili beklenti ve algılamaya bakıldığında ise; kostümler, filmde kullanılan mekanlar/dekor, eğiticilik, çocuklarla da gidilebilecek bir film olması ve ilgi çekici olayların olması gibi konularda izleyicilerin filmle ilgili algılamalarının beklentilerinden yüksek olduğu görülmektedir. Yani araştırma sonuçlarına göre, film genel olarak, bu özellikler açısından izleyicileri tatmin edebilmiştir (Çakmak ve Cengiz 2016: 57$58)$.

Film, Fatih Sultan Mehmet'in tahta ikinci kez geçtiği 1451'den İstanbul'u fethettiği döneme kadar olan süreci anlatmaktadır. Medine 627 tarihiyle başlayan film, bir kartalın çöl üzerinden uçarak Konstantiniye'ye Sultan Mehmet'in doğum tarihine gelmesiyle devam eder. Fatih Sultan Mehmet'in doğum tarihindeki bir takım mistik olayların dış ses anlatımıyla devam filmde, 1432'de atların ikiz doğurduğu, toprağın bereketten dört kez ürün verdiği, ağaçların meyvelerinden yerlere kadar eğildiği, Bizans surlarının önünden bir kuyruklu yıldız kayıp, aşılamayan surların aşılabilir olduğunu gösterdiği, Bizans topraklarında gökyüzünün karardığı belirtilerek, dini referanslarla Fatih Sultan Mehmet'in İstanbul'u fethedecek kişi olduğunun daha doğumundan itibaren bilindiği aktarılmaktadır. Sultan Mehmet'in doğumundan tahta ikinci kez geçeceği zamana kadar olan süreç, bir anlatıcı tarafından özetlendikten sonra Sultan Mehmet'in babasının ölümünün ardından tahta geçişi ile hikayenin gelişimi başlamaktadır.

Sultan Mehmet'in tahta geçişi Bizans tarafından memnuniyetle karşılanır, çünkü Mehmet daha önce tahta çıkmış ama babasının geri dönmesiyle tahtan indirilmiş zayıf bir padişah olarak görülür. Halkının ve ordusunun kendisine güveni yoktur. Bizans bu durumdan faydalanmak ister. Ancak tüm bu olanlara sadece Grandük Notaras karşı çıkar ve Mehmet'in bu süre zarfında geçirdiği dönüşüm onun ağzından izleyiciye aktarılır. Notaras "Şehrin savunmasını yarmak için mühendislik ilimleri öğrendi. Zayıf yönlerimizi anlamak için dilimizi, inancımızı boğmak için 
dinimizi... Henüz çok genç olabilir ama o deccalin ta kendisidir." diyerek aslında Sultan Mehmet'in ne kadar yetenekli, ileri görüşlü, zeki ve azimli biri olduğunu ve aynı zamanda verdiği kritik kararlarla değerli bir devlet adamı olduğunu anlatmaktadir.

İlerleyen sahnelerde Sultan Mehmet'in “İktidar halka güç gösterisi yapmak değildir. Halkın çıkarlarım korumak, refahını sağlamak ve geleceğini inşa etmek için bir araçtır. Bir sultanı güçlü yapan da budur." sözleri onun Bizans İmparatoruna kıyasla daha genç olmasına rağmen çok daha iyi bir devlet adamı olduğunu izleyiciye gösterir niteliktedir. Bu tür sahneler ile filmin başından sonuna kadar Sultan Mehmet'in devlet adamlığı ve zekası yüceltilmektedir.

Film, bir yandan Osmanlı'daki devlet içi iktidar mücadelesini diğer yandan da Bizans, Avrupa ve Papa'nın bakışını ortaya koymaktadır. Bu iki karşıt konum “biz" ve "öteki”nin inşasını sağlamakta, tıpkı tarihi kostüme filmlerde olduğu gibi Türk ve Müslümanlar “biz” iken, başta Bizans olmak üzere Vatikan ve diğer batılı Hristiyan devletler "öteki” olarak yansıtılmaktadır. "Biz" içinde herkes Müslüman kimliğinde birleşmekte iken onlar kendi içinde bile parçalanmış olarak yansıtılmakta ve Hristiyanlık içindeki mezhep kavgaları vurgulanmaktadır. Filmde Bizans halkını ve inançlarını dahi II. Mehmet'in hoşgörüsünün kurtaracağına dair söylemler Grandük Notaras ve Papaz Genadius tarafında dile getirilmektedir. Her ikisi de Latinleri, Katolikleri ve Papayı ülkelerinde görmek istemediklerini söylemekte ve Notaras "Şehrimizde Latin külahı görmektense Türk sarığı görmeyi tercih ederim." diyerek Batıya ve Katolik kilisesine karşı tutumunu açıkça ifade etmektedir. Ancak Bayrı (2013: 81-82), Ortodoks kilisesinin batı karşısındaki bu aciz durumunun tarihi gerçeklerle çokta uyuşmadı̆̆ını vurgulamaktadır. 14. ve 15. yüzyılda Bizans kilisesinin etkili olduğu coğrafyanın Bizans sınırlarından çok daha geniş olduğunu belirtmektedir. Ayrıca filmdeki dini vurgularla ilgili bir diğer hatanın da Osmanlı ordusunda savaşan askerlerin 
tamamının Müslümanmış gibi bir izlenim yaratılmasından kaynaklandığını söylemektedir.

Filmde dine yapılan vurgu bununla da sinırlı kalmamakta, taaruz öncesi namaz kılma sahnesi, tekbir getiren savaşçıların Bizans'a yaydığı korku, Bizans surlarını tünel kazarak aşmaya çalışan kahraman lağımcıların tekbir getirdiği sahneler ve bilerek, isteyerek ölüme gidişleri dinin bağlayıcı bir güç olduğunu göstermektedir. Filmin kostüme avantür filmlerle bir diğer benzer özelliği de Türk erkek kahramana aşık olan ve aşkından din değiştirip Müslüman olan Rum ya da Bizanslı Hristiyan kadın karaktere, biraz farklılaşmış olsa da, yine rastlanmasıdır. $\mathrm{Bu}$ defa din değiştirme zahmetine girmeden Era karakteri çok küçük yaşta kaçırılan gerçekte Müslüman olan bir kadın olarak yansıtılır. Şövalye Giistiniani'nin aşkına karşılık vermeyen Era ve Ulubatlı Hasan ilk görüşte karşılıklı bir etkilenme yaşamışlardır ve filmin sonunda da Ulubatlı ölürken Era'nın hamile olduğu izleyiciye hissettirilmiştir.

Filmde, İstanbul fethedildikten sonra şehrin halkı Ayasofya'ya sı̆̆ınır, Bizans imparatoru öldürülür. Sultan Mehmet şehre girdiğinde ilk iş olarak imparatorlarını dinlere uygun şekilde defnetmelerini söyler ardından Ayasofya'ya sığınan Bizans halkı ile konuşur. Çoğunluğu kadın ve çocuklardan oluşan halka "Korkmayın, bundan böyle canımız bir, malımız bir, kaderimiz birdir. İnancınızı dilediğiniz gibi yaşamakta serbestsiniz." diyerek kendine gülümseyen bir çocuğu kucağına alır ve kendisini öpmesine izin verir. Kendi oğluna göstermediği şefkati bu çocuğa gösteren Sultan artık Türklerin mazlum değil, muktedir olan olduğunu göstermektedir.

Geçmişin sadece bir görüntüsünü sunmakla kalmayıp, güçlü bir duyguya sahip olmamızı da isteyen ve bizi yaşanan deneyime ortak etmeye çalışan filmlerin, özellikle ana akım sinema söz konusu olduğunda tarihi nasıl inşa ettiğini Rosenstone altı maddede toplamaktadır. Rosenstone'a göre, anaakım filmler öncelikle tarihi hikayeleştirmektedirler. Bireysel öyküler sunmaktadırlar. Kendi 
içinde kapalı, tamamlanmış ve basit bir yapı inşa ederek, ekranda görünen dışında herhangi bir alternatif olasılığı bırakmamaktadırlar. Duygusallaştırıp, kişiselleştirip ve dramatize ederler. Görüntü sanatının, renkler ve hareketler, müzik ve ses efektleri, yakın plan çekimi ve kurgu gibi tüm özel olanaklarını kullanarak seyircide bir olayı seyretmenin ötesinde, deneyimlediği duygusu yaratmaya çalışırlar. Filmler, tarihi bir süreç olarak gösterirler. Yazılı tarih ekonomi, politika, ırk, sınıf, toplumsal cinsiyet vb kategorizasyonlar kullanırken filmler bütüncül bir anlatıyı tercih ederler. Filmler ele aldığı dönemi tüm detaylarıyla görselleştirerek geçmişe bir "bakış" atmamızı sağlamaktadırlar (Rosenstone 1995a: 8-9). Bu sinıflandırma bağlamında ele aldığımızda Fetih 1453'ün tarihi duygusallaştırarak, dramatize ettiği görülmektedir. Gerçek bir olaydan hareket etmekte ancak olayı tek bir bakış açısı ile ele alarak olayları hikayeleştirmektedir. Bunu yaparken tıpkı Rosenstone'un belirttiği gibi sinematografik öğelerden de yararlanmaktadır. Film boyunca Sultan Mehmet'in dövüş sahneleri yavaş çekimlerle ustalığını gösterecek şekilde verilmiş, ses efektleri ve müzikle bu sahneler desteklenmiştir. Kuşatma sırasında Bizans topraklarında sürekli karanlık hakim olmuş, çaresizlikleri ve içinde bulundukları zor durum görsel olarak da izleyiciye hissettirilmiştir. Klasik anlatının tüm görsel ve anlatısal özelliklerini kullanan film gerçek bir olaydan hareket etmesine karşın hikayeyi efsaneleştirerek izleyiciye sunmuştur.

\subsection{Bugünün Gözüyle Geçmişe Yeniden Bakmak}

Toplumsal belleğin yeniden üretilmesinde izleyiciye tarihsel olaylar, kişiler ya da çeşitli konular hakkında bir şeyler söyleyen filmler, bir yandan da tarihsel gerçeklikler üzerine bir yeniden üretimde bulunmaktadırlar. Aynı tarihi olaya farklı dönemlerde nasıl bakıldığı̆, içinde bulunulan dönemin toplumsal, siyasal ve ekonomik yapısı ile yakından ilgilidir. Bu nedenle tarihi filmler her ne kadar geçmişi temsil etse de bugünü de yansıtmaktadırlar. 
Fetih 1453 anlatı yapısı ve konunun işlenişi açısından değerlendirildiğinde prodüksiyon açısından geçmişe nazaran çok daha nitelikli olsa da tarihi kostüme filmlerin devamı niteliğindedir. 1960-1970'lerin sosyo-politik ortamında doğan tarihi kostüme filmlerin ruhu adeta 2000'ler Türkiye'sinin siyasi ve toplumsal ruhuna uygun olacak şekilde yeniden perdeye aktarılmıştır.

Temeli 27 Mart 1994'teki yerel seçimlere kadar uzatılabilecek olan bu politik söylem Necmettin Erbakan'ın liderliğindeki Refah Partisinin yerel seçimle ilgili konuşmalarında kendini göstermektedir. İstanbul belediye seçimlerini “İstanbul'un ikinci fethi” olarak tanımlamakta ve İstanbul'u alarak onu yeniden "Bizanslaştırmak" isteyenlerin umutlarını boşa çıkarmak istediklerini beyan etmektedirler (Bayrı 2013: 82). 1999 depremi ve 2001 krizinin hemen ardından iktidara gelen ve yeni kurulan bir parti olan Adalet ve Kalkınma Partisi de Refah partisinin bu çizgisini devam ettirmiş ve parti lideri Recep Tayyip Erdoğan her fırsatta İstanbul'a verdiği önemi vurgulamıştır ve bu önem günümüze kadar devam etmiştir.

"İstanbul'un fethi" Türkiye için güçlü bir metafordur. Hem Batının çevresi olarak kabul edilebilecek Türkiye'nin merkezdeki batıyla hem de doğu-batı ilişkisine gönderme yapmaktadır (Bayrı 2013: 82). Bu anlamda güncelliğini hala devam ettirmektedir. AKP, sosyal ve ekonomik anlamda "çevre" den gelmekte ve tabanı itibariyle orta ve alt sınıflara dayanmaktadır. Merkez çevre yaklaşımı Türkiye'nin siyasal ve sosyal yapısının çözümlenmesinde de bu anlamda anahtar konumda olmuştur. Merkezin dayanak noktası olarak kabul edilen toplumu yönetenlerin dayandığı değer, sembol ve inanç özellikleri, merkeze ve dolayısıyla da merkezin iktidarını kullananlara kutsiyet atfedilmesine zemin hazırlamaktadır (Tuncel ve Gündoğmuş 2012: 139-140). Bu bağlamda günümüz Türkiye'sinde İstanbul'un fethinin popüler kültürde yansıması ve bunun toplumun bir bölümü tarafından algılanışının çevrenin merkeze karşı zaferi ve çevre merkez ilişkilerinin bir metaforu olduğu iddia edilebilir (Bayrı 2013: 83). 
İktidara gelişiyle Batı ile ilişkileri hızlandıran ve Avrupa Birliğine girme konusunda önemli adımlar atan AKP iktidarı 2004 yılında Türkiye'nin uzun yıllar süren Avrupa Birliği macerasında önemli bir dönemece girmesini sağlamıştır. Tam üyelik sürecini başlatacak önemli bir aşama olan müzakere tarihi alınmış, 2005 tarihinde müzakereler başlamıştır. Fakat ilerleyen zamanlarda kimi müzakere başlıklarının askıya alınması ile süreç yavaşlamıştır. Geçmişe nazaran Avrupa Birliği'nin kendi içinde sorunlu bir dönem yaşaması ve kendi birliği içinde yaşanan ekonomik krizler ve Türkiye'nin bu dönemdeki istikrarlı seyri de iç politikada "mazlum" değil "kudretli" olma psikolojisine sebebiyet vermiştir (Bayrı 2013: 83).

2012 yapımı Fetih 1453'te bu çerçevede Türkiye'de son dönemlerde politik yeniOsmanlıcılık ideolojisinin toplumda benimsenmesinin bir yansıması olarak değerlendirilebilir. Osmanlıya ilişkin hatıraların canlandırılması, Osmanlı tarihi ile sıkı bir bağ kurulması, gündelik hayat ve kültürel politikalarda Osmanlı imajının canlı ve yaşayan bir övünç kaynağı olarak sunulması olarak algılanabilecek olan yeni-Osmanlıcılık, Türkiye'de özellikle Özal döneminden ve kısmen Çiller döneminden sonra, 2000'li yıllarda Ak Parti iktidarları ile gelişme göstermiştir. Bu dünya görüşü hem devlet politikası olarak hem de toplum düzeyinde karşılık bulmuştur (Osmanbaşoğlu 2018: 5, Erdem 2017: 713-714). Kavram ilk defa 1970'li yıllarda Kıbrıs Türklerine yapılan müdahaleler sonucunda Kıbrıs'ta Türkiye'nin varlık göstermesi ile Yunanistan'da kullanılmıştır (Ongur 2015: 423). Bu anlamda yeni-Osmanlıcılık başkaları tarafından ortaya atılan bir kavramın esasen yeniden üretilerek farklı dönemlerde kendimizi tanımlamak için kullanma eğilimi olarak görülebilir (Osmanbaşoğlu 2018: 3).

Kavramın ortaya atıldığı yılların tarihi kostüme filmlerin en çok çekildiği ve izleyici bulduğu yıllar olması ve 2000'li yıllar sonrası hem devlet politikası olarak hem de halk arasında kabul görmesiyle türün yeni örnekler vermeye başlaması tesadüf olarak nitelendirilememektedir. 
Erdem, Foucault'nun governmentality kavramindan esinle ortaya attığ1 Ottomentality kavramını, Fetih 1453 filmi ve Muhteşem Yüzyıl dizisi örnekleminde tartışmış, yükselen politik söylem ile popüler kültür alanında verilen bu ürünlere ilginin artışına değinmiştir. Bu anlamda yeni-Osmanlıcılık ve fetihin sadece geçmişteki Osmanlı imparatorluğuna değil bugünkü Türkiye Cumhuriyetinin yaşanan gerçekliğine de vurgu yaptığını dile getirmiştir. Erdem, Panorama 1453 müzesinin, Fetih 1453 filminin, İstanbul'un fethinin her y1l törenlerle kutlanmaya başlamasının bu politikaların bir sonucu olduğunu belirtmekte, bu bağlamda Fetih 1453 için AKP yetkililerinin övgü dolu ifadelerini hatırlatmaktadır (2017: 720-723).

Filmin yönetmeni Aksoy ise "Her şeyden önce yapılanın bir sinema filmi olduğunun, ortak gurur ve değerlerimiz üzerine inşa edildiğinin, her yapımcının hayalindeki konunun sinemaya aktarımı olduğunun bilinmesi gerekir. Film üzerindeki siyasi ve tarihi tartışmaların tamamen uză̆ında olduğumuzu belirtmek isterim. Yüklenen anlamlar kişilerin kendi görüşleridir" diyerek filmle ilgili siyasi ve tarihi tartışmalardan uzak olduğunu belirtmektedir. (http://www0.haberler.com/fetih-1453-filmininyonetmeni-elestirileri-3386786-haberi/, erişim tarihi: 5.01.2019).

Aksoy'un açılamasına benzer bir açıklamada aynı dönemlerde Amerika'da gösterime giren ve aynı tartışmalara neden olan Lincoln filminin yönetmeni Steve Spielberg'den gelmiştir. Spielberg kendisini eleştiren tarihçilere, "Tarihin bilinmeyen yerleri hakkında konuşmak tarihçiler açısıdan işlerine ihanettir. Ancak, filmci, kendi yaratıcı hayalgücü ile tarihin karanlık yerlerine kendince ışık tutar. Hiç şüphesiz bu en iyi şekilde yapıldığında bile sadece bir fantezi ve hayaldir. Sanatın işlerinden biri de tarih biliminin girmekten kaçınması gereken yerlere girmesidir" (http://amerikabulteni.com/2012/11/28/abdde-muhtesem-tartisma-tarihciler-lincoln-filminetepkili/, erişim tarihi: 18.12.2018) diyerek yönetmen olarak tarihi birebir yansıtma zorunluluğu olmadığını tam tersine hayal dünyasının ön planda olduğunu dile getirmiştir. 
Toplin ve arkadaşları tarihsel filmlerin, her birinde tamamı bulunmasa da, ortak bazı özeliklere sahip olduğunu vurgulamaktadır. Yazarlara göre, sinematik tarih, tarihi kanıtları basitleştirip pek çok detayı dışarda bırakmakta, serim, düğüm ve çözüm bölümleriyle geleneksel anlatıyı benimsemekte, geçmişi taraflı bir biçimde ortaya koyup, iyi-kötü ayrımını açık bir biçimde göstermekte, ahlaki ders veren hikayeler anlatmakta, şimdiki zamana hitap etmekte, olayların merkezinde olmasa da sıklıkla hikayelere aşk ilişkilerini yerleştirmekte ve görüntü ve sesle güçlü bir etkileşim kurmaktadır (akt. Stubbs 2013: 14). Hem Aksoy'un hem de Spielberg'ün filmleri ve filmleri ile ilgili açıklamalarına bakıldığında Toplin'in tarihi filmler ile ilgili belirtmiş olduğu pek çok unsurun filmlerde yer aldığı ve yönetmenlerin bu eleştirilere cevap verme gereği duyduğu görülmektedir.

Klasik anlatı yapısını benimseyen, içerisine aşk öykülerini yerleştiren, anlattığı konu itibariyle çatışma unsurunu bizzat bünyesinde barındıran film geçmişi anlatırken aynı zamanda şimdiki zamana da hitap etmektedir. Fetih 1453 filminde kahramanlık anlatıları ve zaferler aracılığıyla, "şanlı mazi" "başarı"larla dolu geçmiş hatırlatılmakta ve resmi ideoloji canlı tutulmaktadır. Tıpkı kendinden önceki pek çok tarihi ele alan filmde olduğu gibi sınırlı bir bakış açısına yer vermekte ve olaylar bir kahramanlık destanı şeklinde anlatı içinde aktarılmaktadır. Film, geçmişi, tarihsel bir bakış açısıyla taraflarıyla ele almak ya da yorumlamak, eleştirmek fikrinden uzak popüler bir söylem içinde değerlendirmektedir.

Tarihsel filmlerin tümünün kurgusal olduğunu, bundan nedenle bazı kayıtlara dayansa bile, gösterdikleri şeyin büyük bölümünü hayali bir şekilde yeniden inşa ettiklerini ifade eden Sorlin'in de belirttiği gibi, gerçek olaylar ve hayali kısımlar birleştirilmektedir (Akt. Göze 2018: 308).

Sonuç olarak geçmiş geçmişin çizgisinden ayrılmamak, geçmişi canlı tutmak amacıyla hafızaya davet edilmektedir. Bugünü geçmişin belli unsurları temelinde kurma hedefi söz konusudur ve bu nedenle de, gurur duyulan, dönemler 
hatırlanıp, hatırlatılmakta kolektif belleğe işlenmek istenmekte ve toplumsal bellek bu yönde oluşturulmaktadır.

\section{SONUÇ}

Geçmişin hatırlanmasını basitçe bilgileri geri getirme işlemi değil de aktif ve yapıcı bir süreç olarak kabul ettiğimizde toplumsal bellek yeniden inşalar ürünü olarak karşımıza çıkmaktadır. İçinde yaşadığımız toplumsal şartların çerçevesi doğrultusunda geçmiş olaylar kavranmakta ve değerlendirilmektedir. Bu inşa sürecinde kimi olaylar göz ardı edilmekte, kimileri değiştirilmekte kimileri ise yok sayılmaktadır. Bu durum özellikle unutmak, geçmişte bırakmak, hatırlamamak istediğimiz geçmişimiz söz konusu olduğunda ortaya çıkmaktadır. Ancak tam tersi durumlarda ise geçmiş olaylar özellikle ön plana çıkarılmakta, sürekli tekrarlanarak hatırlatılmakta ve "şanlı tarihimiz" söylemi sıklıkla belirtilerek bugün yaşanan sıkıntılara rağmen geçmiş başarıların unutulmaması gerektiği vurgusu yapılmaktadır. Yani geçmişin nesnel bir sunumunu vermek yerine, genellikle geçmiş mevcut kültürel değerlere veya siyasi amaçlara uygun şekilde sergilenmekte, bireylere belirli bir toplumsal grubun veya ulus devletin hedef ve inançlarını yansıtan bir geçmiş aktarılmaktadır.

$\mathrm{Bu}$ anlamda öznel seçimlerle bir anlatıya dönüştürdüğümüz bir kurgu olan toplumsal bellek inşasında, yapısı itibariyle kurgu olan sinema filmleri de önemli bir "hafıza mekan"1 olarak karşımıza çıkmaktadır. Anlatı içinde tarihin hangi parçasının seçildiği, filmlerin bu dünyayı nasıl yarattığı ve sunduğu ve seçilen bölümlerin anlatıya uygun olarak nasıl revize edildiğinden başlayarak geçmişin aktarılma şekline kadar sinema önemli bir işlev görmektedir. Dönemin siyasi anlayışı ve ideolojisi doğrultusunda tarih aracılığıyla topluma "kim oldukları, nereden geldikleri" hatırlatılmakta, toplumu yönlendirmede tarihe göndermede bulunarak bir takım görüşler temsiller yoluyla aktarılmaktadır. Popüler sinema söz konusu olduğunda bu aktarım resmi tarih söylemleri doğrultusunda gerçekleşmektedir. 
Faruk Aksoy'un yönettiği 2012 yapımı Fetih 1453 yaklaşık olarak 6,5 milyon seyirciye ulaşmış, 18 milyon dolarlık bütçesiyle en pahalı yapımlardan biri olarak Türk sinemasında tarihsel filmler arasındaki yerini almıştır. Kendinden önce çekilmiş İstanbul'un fethi filmlerinden bilgisayar teknolojisinin yardımıyla oluşturulmuş savaş sahneleri ve efektlerle farklılaşan filmde, kahramanlık anlatıları ve zaferler aracılığıyla, "şanlı mazi" "başarı"larla dolu geçmiş hatırlatılmış ve resmi ideoloji canlı tutulmuştur. Tıpkı kendinden önceki pek çok tarihi ele alan filmde olduğu gibi sınırlı bir bakış açısına yer vermiş, film, geçmişi, tarihsel bir bakış açısıyla taraflarıyla ele almak ya da yorumlamak, eleştirmek fikrinden uzak popüler bir söylem içinde değerlendirmiştir. Film, Osmanlıya ilişkin hatıraların canlandırılması, Osmanlı tarihi ile sıkı bir bağ kurulması, gündelik hayat ve kültürel politikalarda Osmanlı imajının canlı ve yaşayan bir övünç kaynağı olarak sunulması olarak algılanabilecek olan yeni-Osmanlıcılık ideolojisinin toplumda benimsenmesinin bir yansıması olarak da değerlendirilebilir.

Prodüksiyon bağlamında kostüm, dekor, vb. öğeler açısından kendinden önceki tarihsel filmlerden farklılaşsa da temel ideoloji ve bakış açısından kendinden önce üretilmiş kostüme avantür filmlerle arasında çok büyük bir fark olmadığı dikkat çekmektedir. $\mathrm{Bu}$ bağlamda filmin, toplumsal bellek algısının oluşturulması yönünde işlev gördüğ̈ü söylenebilir.

\section{KAYNAKLAR}

Assmann J (2001) Kültürel Bellek, Ayrıntı Yayınları, İstanbul.

Assmann J (2008) Communicative And Cultural Memory, Erll, A. \& Nünning (eds), A, Cultural Memory Studies, An International And Interdisciplinary Handbook, 109-118.

Başlar G (2018) " Kullanıcı Üretimi" Kolektif Hafıza: Adalet Yürüyüşü Örneği, Iletis-im, 28, 143-175. 
Bayrı K B (2013) Türkiye'de Popüler Kültürde Bizans Metaforu, Toplumsal Tarih, $232,77-83$.

Bilgin N (2013) Tarih Ve Kolektif Bellek, Bağlam Yayınları, İstanbul.

Burke P (2016) Tarihin Görgü Tanıkları, Z. Yelçe (çev), Kitap Yayınevi, İstanbul.

Büyükdüvenci ve S Öztürk S R (2014) Postmodernizm ve Sinema, Dipnot Yayınları, Ankara.

Confino A (1997) Collective Memory And Cultural History: Problems Of Method, The American Historical Review, 102(5), 1386-1403.

Connerton P (1999) Toplumlar Nasıl Anımsar?, Alaaddin Şenel (çev), Ayrıntı Yayınları, İstanbul.

Erkılıç, D S (2012) Türk Sinemasında Tarih Ve Bellek, Deki Yayınları, Ankara.

Ferro M (2017) Sinema ve Tarih, Ayrıntı Yayınları, İstanbul.

Göle M (2007) Doğru Olmadığını Biliyorum Ama Öyle Hatırlıyorum, Cogito, 50, 23-30.

Güney A (2006) Resmi Milliyetçilikten Popüler Milliyetçiliğe Geçiş: 1960 Sonrası Türk Sineması Üzerine Siyasal Bir Deneme, Doğu Batı 39, 209-226.

Gürata A (2007) 'Öteki'yle Üçüncü Türden Yakın İlişkiler: Tarihsel Kostüme Filmler Ve İkizlik Miti, Deniz Bayrakdar (der), Türk Film Araştırmalarında Yeni Yönelimler-6, Bağlam Yayınları, İstanbul, 43-56.

Gürata A (2009) Tarih Aynı Zamanda İnsanların Eğlendiği Bir Alan Olmalı, Cemal Kafadar İle Söyleşi, Kebikeç, 27, İstinye, 109-130.

Hoskins A (2004) Television and The Collapse Of Memory, Time \& Society, 13(1), 109-127.

http://amerikabulteni.com/2012/11/28/abdde-muhtesem-tartisma-tarihciler-lincoln-filminetepkili/. 
http://www0.haberler.com/fetih-1453-filminin-yonetmeni-elestirileri-3386786haberi/.

https://boxofficeturkiye.com/tumzaman/?tm=1989.

Huyssen A (1999) Alacakaranlık Anıları, Bellek Yitimi Kültüründe Zamanı Belirlemek, Kemal Atakay (çev), Metis Yayınevi, İstanbul.

İnce, G. B. (2010) Medya ve Toplumsal Hafıza, Kültür ve İletişim, 13(1), 9-29. İspi G (2007) “Tarihi" Türk Filmlerinde "İyi Ve Kötü Adam" Olmak" Deniz Bayrakdar (der), Türk Film Araştırmalarında Yeni Yönelimler-6, Bağlam Yayınları, İstanbul, 57-64.

Makal O (2014) Sinemada Tarihin Görüntüsü, Kalkedon Yayınları, İstanbul.

Meusburger P (2011) Knowledge, Cultural Memory, and Politics, Heffernan M ve Wunder E (eds), Cultural Memories, Springer Science \& Business Media.

Nora P (1989) Between Memory And History: Les Lieux De Mémoire, Representations, 7-24.

Nora P (2006) Hafıza Mekanları, M. E. Özcan (çev), Dost Kitabevi Yayınları, Ankara.

Olick J K (2014) Kolektif Bellek: İki Farklı Kültür, Meral Güneşdoğmuş (çev), Moment Dergi, Hacettepe Üniversitesi İletişim Fakültesi Kültürel Çalışmalar Dergisi 2014, 1(2): 175-211.

Ongur H O (2015) Identifying Ottomanisms: The discursive evolution of Ottoman Pasts in The Turkish Presents, Middle Eastern Studies, 51(3), 416-432.

Osmanbaşoğlu G K (2018) Ortadoğu'da Barışı Tesis Etmede Neo-Osmanlıcılık Bir Seçenek Olabilir Mi?, Akademik Hassasiyetler, 5(9), 1-15.

Özön N (1984) 100 Soruda Sinema Sanatı, Gerçek Yayınevi, İstanbul. 
Öztaş S ve Anıl N K ve Kılıç B (2013) Tarihi film veya tarihi dizilerin tarihe ilgiyi artırmada etkisine ilişkin MYO öğrencilerinin görüşleri, Electronic Journal of Vocational Collages, 3(4), 107-120.

Pennebaker J ve W Gonzales A L (2015) Tarih Yazmak: Kolektif Belleğin Altında Yatan Sosyal Ve Psikolojik Süreçler, Pascal Boyer Ve James V. Wertsch (eds), Zihinde Ve Kültürde Bellek, Türkiye İş Bankası Yayınları, İstanbul, 217-245.

Roediger H. L Zaromb F M Butler A C (2015) Kolektif Belleğin Şekillendirilmesinde Tekrarlanan Hatırlamanın Rolü, P. Boyer Ve JV Wertsch (eds), Zihinde Ve Kültürde Bellek, Türkiye İş Bankası Yayınları, İstanbul, 175-216. Rosenstone R A (1995a) The Historical Film as Real History, Film-Historia, Vol. V, No.1. 5-23.

Rosenstone R A (1995b) Revisioning History: Film and The Construction of a New Past, Rosenstone R A (eds), Princeton University Press.

Sancar M (2016) Geçmişle Hesaplaşma: Unutma Kültüründen Hatırlama Kültürüne, İletişim Yayınları.

Schudson M (2007) Kolektif Bellekte Çarpıtma Dinamikleri, Begüm Kovulmaz (çev), Cogito, 50, 179-199.

Scognamillo G ve Demirhan M (1999) Fantastik Türk Sineması, Kabalcı Yayınevi İstanbul.

Stubbs J (2013) Historical Film: A Critical, İntroduction, Bloomsbury Publishing. Suner A (2006) Hayalet Ev: Yeni Türk Sinemasında Aidiyet, Kimlik Ve Bellek, Metis yayınları, İstanbul.

Şahin M (2014) 2000 Sonrası Türk Sinemasında Tarihi Filmlerde Milli Kimliğin Yeniden İnşası, Yüksek Lisans Tezi, Anadolu Ün. Sos. Bil. Ens, Eskişehir. 
Tuncel G ve Gündoğmuş B (2012) Türkiye Siyasetinde Merkez-Çevrenin Dönüşümü Ve Geleneksel Merkezin Konumlanma Sorunu, Gazi Üniversitesi İktisadi ve İdari Bilimler Fakültesi Dergisi, 14(3), 137-158.

Wertsch J V (2015) Kolektif Bellek, Pascal Boyer Ve James V. Wertsch (eds), Zihinde Ve Kültürde Bellek, Türkiye İş Bankası Yayınları, İstanbul, 149-174.

West C (2011) Memory-Recollection-Culture-Identity-Space: Social Context, Identity Formation, And Self-Construction Of The Calé (Gitanos) İn Spain, In Cultural Memories Springer, Dordrecht. 101-119.

Yang Erdem C (2017) Ottomentality: Neoliberal Governance Of Culture And NeoOttoman Management Of Diversity, Turkish Studies, 18(4), 710-728. 